UDC 394.912+821.113.6

Tatiana Konopleva, Olga Pechinkina

Northern (Arctic) Federal University named after M.V. Lomonosov

\title{
LEARNING ABOUT SWEDISH CULTURE FROM SVEN NORDQVIST'S BOOKS (CASE-STUDY: PETTSON AND FINDUS BOOK SERIES)
}

For citation: Konopleva T. O., Pechinkina O. V. Learning about Swedish culture from Sven Nordqvist's books (case-study: Pettson and Findus book series). Scandinavian Philology, 2018, vol. 16, issue 2, pp. 340-355. https://doi.org/10.21638/ $11701 /$ spbu21.2018.210

In a globalized world knowledge of values and peculiarities of other cultures becomes an indispensable condition for successful cross-cultural communication, promotes a deeper awareness of one's own culture, develops tolerance and facilitates political, economic, cultural and other contacts between countries. One of the sources of acquiring background knowledge is literary text, in which authors recreate objective reality of their countries. Well-translated and nicely illustrated children literature allows readers to get acquainted with peculiarities of other cultures from a very early age. The aim of the article is to study the reflection of Swedish culture in Sven Nordqvist's books written and illustrated for children. Nordqvist's books, namely the book series about Pettson and Findus, have become popular all over the world. The main character named Pettson is an old Swedish farmer who lives on his own in a traditional red country house surrounded by a garden until the day when a restless kitten, whom Pettson without a moment's hesitation calls Findus, appears in his ordered life. From that day on his main task is to ingeniously solve the problems which Findus gets into. Books about Pettson and Finds are translated into many languages, made into cartoons and educational programmes. Illustrations made by Sven Nordqvist make the books special as they supplement the textual information about Sweden, its geographical setting, benefits of living a rustic life, traditions, holidays, cuisine, inventions, etc. Sven Nordqvist manages to capture the spirit of living in Sweden all year round. He gives his readers the opportunity to get peculiar knowledge of Swedish culture, necessary for effective interaction with the representatives of a different cultural background.

Keywords: Sven Nordqvist, Swedish culture, cross-cultural communication, traditions. 
Nowadays it's impossible to imagine any activity of a person without integration into the world community. People exchange their experience, master their skills, get new impressions when they study, work, travel, read books, etc. In order to be successful in cross-cultural communication, which is "a communication of the language personalities belonging to various linguocultural communities" [Andreyeva et al., 2015, s. 209] an individual should possess relevant and actual knowledge, skills and competences. It's not enough to acquire and master "a verbal code (a foreign language) only, but also an extra code (background knowledge), which can positively influence the development of cross-cultural relations, and help to reduce the frequency of communicative failures" [Kramsch cited in Andreyeva, 2015, s. 209]. According to G. N. Rzaeva, M. R. Mustafaeva and D. F. Mamedova "the effectiveness of cross-cultural communication depends on many factors: peculiarities and culture of communication, rules of etiquette, knowledge of nonverbal forms of expression, background knowledge in general, and many other things" [Rzaeva, 2017, s. 32]. It is evident that there is a need for a deeper and more thorough study of the world of native speakers, their culture, way of life, national character and mentality.

It should be noted that the term 'background knowledge' has a wide meaning. Taking into account definitions of the term given by O.S. Akhmanova (mutual knowledge of realities by the speaker and the listener) and V.S. Vinogradov (sociocultural information, characteristic of a certain nation or nationality, mastered by its representatives and reflected in the language of the national community), M. A. Khavanskaya comes to the conclusion that background knowledge implies knowledge of specific realities. A multicultural personality is developing in the process of forming background knowledge, becoming aware of self identity in the multicultural perspective and tolerant towards representatives of a different cultural background, and interacting effectively with them [Khavanskaya, 2015, s. 157]. Undoubtedly, many cultures possess common features, although specific realities are those unique traits which are characteristic for representatives and non-representatives of a culture. These realities have their own history meaningful for representatives of a particular culture and give them the right to be proud of their country and culture. For this reason it is necessary to consider not only principal differences between cultures, but also the details no matter tiny they may seem. 
According to O.A. Andreyeva et al., "acquisition of cross-cultural communicative competence which represents functional abilities to understand views and opinions of representatives of other cultures, to alter the behaviour, to overcome the conflicts in the course of communication, to recognize the right for existence of various values, behaviour norms becomes the most demanded for the modern expert" [Andreyeva et al., 2015, s. 210]. In the process of acquisition of cross-cultural communicative competence a special attention should be paid to social globalization, which touches upon "such areas as science, education, ideology, culture, ethics, etc., erecting new barriers on the already difficult way of cross-cultural communication, generating not only interpenetration, but also interaction of cultures that leads to their serious changes, which might be either negative or positive" [Surovneva et al., 2017, s. 391]. We realize that the two spheres are inseparable, as far as they are interconnected. Communication with barriers is still possible, but only a formal communication, when the parties are not interested in continuing and developing their interaction. Knowledge of the other culture influences the person's own culture introducing certain changes and permitting to preserve peculiarities thus making this person's life, society and culture more vivid, memorable and authentic.

Researchers A. A. Surovneva and P. V.Prokhoda [Surovneva et al., 2017] find both advantages of cultural changes resulting from globalization (acceleration of socio-cultural dynamics, significant increase in the amount of information consumed by an individual, overcoming of political boundaries and ideological and intercultural communication barriers that seemed to be unshakable, allowing to form a single spiritual space where the values of the representatives of different civilizations are accumulated), and disadvantages (unification of moral values, destruction of cultural identity and traditional values of authentic cultures, rise of nationalism, extremism, chauvinism and xenophobia, increasing of contradictions and conflicts all around the world). Scientists come to the conclusion that, in order to avoid the negative consequences of globalization, cross-cultural communication should be based on the principle of mutual tolerance.

The study and acceptance of other cultures should be based upon the knowledge of the own culture. This process implies being open, but it doesn't mean that a person should infringe his own beliefs and encroach upon his individuality [Surovneva et al., 2017, s. 394]. But what does 
the term 'culture' mean? There is a large number of definitions of this term. According to E. I. Kryukova "'culture' means an integral system of learned behaviour patterns that are characteristic of the members of any given society" [Kryukova, 2016, s. 38]. N. P. Bezuglova considers that "culture appears as a complex system composed of partially differently oriented layers that create a large range of varieties, which is manifested in the unity and often 'struggle' of cultures (regional, confessional, etc.), in a wide range of differentiation options between high and folk cultures or subcultures" [Bezuglova, 2017, s. 87]. Representatives of different fields of knowledge have their own interpretations of this term depending on the sphere, object and subject matter of the research and methods. Definitions of 'culture' are multifaceted and will provoke major disputes for many years to come.

However, in terms of this study, it is important to specify the 'components' of culture. According to N.S. Kaplunova [Kaplunova, 2012, s. 101] there are five components, that, somehow, define the national specific: a) traditions (or sustainable elements of culture), as well as customs, defined as traditions and rites; b) household culture, closely connected with traditions, for this reason it is often called traditional and everyday culture; c) daily behaviour (habits of representatives of culture, social conventions adopted in the society, and the mimic code associated with them, d) 'national pictures of the world', reflecting the specific perception of the world, national features of thinking (i.e. mentality); e) an artistic culture reflecting cultural traditions of the ethnos.

As mentioned above, socio-cultural competence implies knowledge of national cultural peculiarities of people's social and verbal code, namely, their customs, traditions, etiquette, stereotypes, history, culture and ways to apply this knowledge in communication [Voluzheva et al., 2013, s. 63]. Formation of this competence is carried out in the context of the so-called dialogue of cultures. It helps people to achieve intercultural understanding and develop their tolerant attitude to a different culture.

Literary text gives people a possibility to participate in the dialogue of cultures and form socio-cultural competence. A literary text is considered as "an act of mediated communication: separated by time, distance, verbal and cultural differences, the author and the reader share the common context and events described the book (...) Creating an imaginary reality on the basis of the objective reality, the author ex- 
presses his viewpoint, outlines implicitly normative settings, models of acceptable encouraged behaviour of the society and culture" [Mandzhiev et al., 2014, s. 154]. The author allows his readers to perceive the national values, i.e. values of his contemporaries and his culture. According to A. A. Mandzhiev and N.I. Chernova [Mandzhiev et al., 2014, s. 154], there are five aspects which provide the reader with the necessary knowledge and skills that contribute to successful communication with representatives of a different cultural background. They are the following:

1. Stereotypes and prejudices;

2. 'Friend or Foe' issue;

3. Culture shock;

4. Acculturation;

5. Collectivism and individualism.

One of the most important criteria for choosing an 'appropriate' book for reading is its contemporaneity, as far as in this case events, situations, lacunas and background knowledge are rather actual and relevant [Mandzhiev et al., 2014, s. 154]. They can give a better understanding of another culture. Books, be it fairy-tales, novels, detective stories, represent a definite model, scenario of people's behavior, their values, preferences and interests. Probably, books are incapable of reflecting and reconstructing all the peculiarities of this or that culture, but they give a general picture and serve as food for future research.

The aim of this article is to study how Swedish culture is represented and reflected in Sven Nordqvist's books. Sven Otto Rickard Nordqvist (born 1946) is a contemporary Swedish writer and illustrator. He studied architecture in Lund and after graduation he started working as a lecturer at the university. Meanwhile, he illustrated different advertisements, posters, and picture books and 1983 won his first prize in a children's book competition. Since then his career as writer and illustrator has started. Nordqvist is best known for his Pettson and Findus book series. Pettson is an old farmer who lives alone in a small red ramshackle house in the country side. One day a neighbour brings him a cat whom Pettson without a moment's hesitation calls Findus according to the frozen food brand printed on the carton box in which the cat is brought [Plahtienko, 2016].

Pettson lives in a world of harmony. "The days come and go and Pettson does what he always has done - cultivates his garden, goes fish- 
ing at the nearby lake (catching perch), makes an invention out of what he has collected in his house, in the attic or things left somewhere in his garden. He listens to the weather report on the radio (a tube radio, certainly) or just quarrels with his cat Findus [Axell et al., 2014].

The stories about adventures of an old farmer and his cat have become very popular among people of different ages and nationalities all over the world. Sven Nordqvist has by now written and illustrated ten books about the ingenious Pettson and his naughty Findus. According to the publishing house "Opal", his books are translated into 47 languages (2015). Stories about Pettson and Findus are made into cartoons and educational programmes.

Except for "The Mechanical Santa", the stories about Pettson and Findus are quite short. Nevertheless, the author manages to reflect enough of a wide range of Swedish realities and society. Evidently, it's not possible to touch upon all peculiarities described and illustrated by Sven Nordqvist within the scope of the article, so, we will briefly dwell on some of them.

\section{HOUSING AND RURAL ENVIRONMENT}

Considering typical rural environment, we notice that the most widespread villages are rather small and sparsely populated. They are located on the banks of a lake or a sea. Such isolated location of rural settlements led to the formation of conformism, manifesting in the aspiration of Swedes to preserve ties and traditions of the community and protect them against penetration of strangers [Gul'ko, 2012, s. 140].

"Gray lake, gray sky, dark forest around ... Leaves have fallen down, bright colours of summer were giving way to the winter palette" [Nordqvist, Findus goes fishing, 2014]. The reader can feel the atmosphere of the place where Pettson and Findus lived: "Everything around was grayish green and brown. Moist air made colours saturated and the forest seemed to be shining bright" [Nordqvist, Findus goes fishing, 2014]. Almost each illustration of the book "Findus goes fishing" depicts a typical autumn landscape of Sweden: conifer forest, huge rocks, bare trees, fallen leaves and a fireman boat in the middle of the lake [Nordqvist, Findus goes fishing, 2014].

Pettson's house was supposedly built in the beginning of the $20^{\text {th }}$ century. The forms and techniques of construction were determined by the 
lack of imported construction materials, mechanisms and work force due to financial deficit. People avoided using concrete in favour of local materials - brick, tile, stone and wood. Handicraft methods flourished in contrast to industrial ones. Architecture of buildings became more picturesque. Wood and plastered brick were used both in exterior and in interior. Intensive colours replaced whiteness, small windows replaced the bigger ones [Ptichnikova, 2016, s. 231].

The house was usually surrounded with a garden which was a kind of a natural forest (pines, birches, etc.). At this period and later architecture was considered as an integral part of a complex environment, where buildings and landscape form a unique body [Ptichnikova, 2016, s. 231].

From the historical perspective, we see that a traditional Swedish farmhouse was usually red. It is surrounded by different household outbuildings which are red as well. This famous red paint called "falu red" originated from Sweden. It consisted of water, rye flour, oil and tailings from copper mines of Falun which contained iron oxides, copper and zinc. It sank deep into wood and reduced moisture absorption to protect it against rot. The earliest evidence of it dates from the $16^{\text {th }}$ century. It was commonly used in Sweden until the early $19^{\text {th }}$ century when people started using paints [Hall et al., 2005].

Pettson lives in one of those typical red farmhouses with a tool shed, a hen house, a woodshed and a garden [Nordqvist, Pancake Pie, 2014]. Nordqvist colourfully depicts Pettson's rustic way of life: his full of tools and gadgets tool shed, messy hen house and well-groomed garden with blossoming apple trees. The interior of his house is rather plain: dingy wallpapers, shabby chairs and benches, a stained cast iron plate, cotton fabric mats on the floor, bristling with all kinds of utensils shelves, a wooden knob bed and all other things make his house look untidy. The attic is littered with old unnecessary things which sooner or later find their application.

Pettson's garden is quite ordinary. There is a number of vegetable beds, red currant bushes, several apple trees and, of course, sunflowers. Wooden garden furniture is forthright and comfortable. Similar tables and chairs can be found in almost every garden in the Swedish countryside and the reader will see the example of them in the book "When Findus was little and disappeared". When Pettson's neighbour Beda Andersson comes to visit him, they are sitting in the garden at the wooden 
folding table painted white, drinking coffee and eating Swedish most traditional cinnamon buns.

Being a handy man, Pettson spends hours in his tool shed. Tool shed is an integral part of any farm house. The absence of curtains on the window lets the daylight in. At the small window there is a large wooden table on which various tools and devices can be found. All of them are neatly organized.

All in all, Pettson's house and dwelling is comfortable and secure. It's his place of life, a refuge, that's why every tiny thing is functional, solid, easy to use, well proportioned, and always beautiful.

\section{CLOTHES}

The development of Swedish folk costume was influenced by natural and climatic conditions. Due to the harsh Northern climate both men's and women's clothing was multi-layered. It initially performed a protective function. Embroidery and ornaments were rather simple and originally served as a protective charm. For the most part traditional folk costume demonstrated the main features of Swedish people - discretion and simplicity [Shvedova, 2016, s. 175].

With the transformation of Sweden from an agrarian society into a modern industrial state the peasant culture as well as folk costumes disappeared. But even today there are Swedes who like dressing up in traditional costumes to mark different festive occasions such as Midsummer and folk festivals. Though folk costumes were different with distinctive local features and ornaments, they had much in common. Regardless of their function, whether they were worn on a daily basis or for a festive occasion, women wore a long linen shirt and a white blouse thereover. The skirt and bodice were either sewn together or separate. An apron was a mandatory part of women's costume. In many parts of Sweden women wore kerchiefs either on their head or over the shoulders. Stockings reached only to the knee and were kept up by garters wound round the leg. On their feet they had heavy leather shoes.

Men wore a long linen shirt with two deep slits at the bottom. It allowed them to serve the same purpose as underpants as they were tucked up between their legs. The breeches ended just below the knee and, in order to protect themselves from cold, men wore long stockings. A waistcoat was an essential part of men's costume [Arnö-Berg, 1976]. 
In the Pettson and Findus series of books the main characters neither daily nor for special occasions put on folk costumes, but the tradition to wear simple cuts and natural fabrics is depicted in the illustrations. Pettson is the generalized character of an average Swedish farmer. He wears gray canvas trousers belted with a piece of rope. Over his simple cotton shirt without a collar he always puts on an old brickred waistcoat. In winter he protects himself from the cold wearing a khaki-coloured sweater and a shabby woolen jacket. His head is always covered with a hat, though in every season the hat is different. A hat has always been a part of the traditional men's folk costume. As a typical Swedish farmer Pettson puts on a wide-brimmed hat when he spends his time gardening, fishing or just walking with Findus. In winter when it gets cold, he has to change his habitual hat for a warmer knitted one. Pettson's footwear is simple but seems to be rather comfortable and solid. In warm seasons he has black leather boots on and when the weather becomes nasty Pettson puts on his pair of old top boots.

His neighbours are also dressed in a simple way. Women's clothing consists of several parts: a shirt or a blouse, a woolen jacket or a knitted cardigan over it and a long skirt. On every occasion women throw a patterned kerchief over the shoulders. When it comes to working in the garden women put on an apron and tie a scarf around the head. In his illustration Nordqvist manages to depict most characteristic features of the everyday peasant clothing of that time.

Nordqvist doesn't often introduce new characters. Friends and neighbours are rare guests in Pettson's house, but when it comes to holidays it becomes rather overcrowded.

\section{TRADITIONS AND HOLIDAYS}

Swedish holidays are traditionally divided into two categories - the Christian and non-Christian holidays. Christian holidays comprise of the classic Christmas, Epiphany, and Easter, and non-Christian holidays include the National Day of Sweden, New Year's Day, Midsummer, etc. Christmas holiday is the biggest and longest holiday of the year. It begins on the first Sunday of Advent when the family gathers together to light up the first Advent candle. Each Sunday prior to Christmas another candle is lit. The $13^{\text {th }}$ of December is the day of St. Lucy. The Lucy procession will visit different public places, such as churches, hospitals 
and shopping malls singing and handing out gingerbread. Christmas traditionally completes the series of winter holidays [Swahn, 2012].

The beauty of December is well-described in "The Mechanical Santa". First of all it's the atmosphere: "it has been snowing for a whole week and the old man's house, the old woodshed, the hen house and the tool shed were covered with a snow blanket", "there was so much to be done (before Christmas) to bake gingerbread and clean the whole house", "Christmas Eve ... The candles on the Christmas tree are lit, the wood is crackling in the stove, it's dark outside the window" [Nordqvist, The Mechanical Santa, 2015]. The window in the dining room is decorated with the traditional Swedish Advents star and the candle holder with four candles, the Christmas tree is trimmed with tiny candles, string flags and gingerbread hearts. Pettson is sitting in the armchair and telling Findus about the day when he got to the hospital and was lucky to see the Lucy procession: "Pettson told how beautiful it was when the girls were proceeding with the candles" [Nordqvist, The Mechanical Santa, 2015, s. 68]. They are listening to the radio and Findus starts singing along the traditional "Santa Lucia", "Silent night" and "Staffan was a stable boy". In the book "Findus at Christmas" when Pettson slipped and hurt his leg, his neighbours come to visit him on Christmas Eve and bring him a lot of tasty things such as traditional Christmas ham, pork sausages, Lutfisk, meatballs, jellied meat, etc. [Nordqvist, Findus at Christmas, 2014]. It's worth mentioning that the neighbours have very widespread Swedish family names (Andersson, Gustavsson, Johnsson, Nilsson, Lindgren) and names (Elsa, Axel).

In each book the reader can come across the illustration on which Pettson is sitting at the table, drinking coffee and thinking deep. It's a well-known fact that Sweden takes the second place after Finland when it comes to coffee consumption.

\section{TECHNOLOGY AND INNOVATIONS}

Pettson likes technologies and inventions. All over the world Swedes are known as a nation of inventors and innovators, and they still preserve their aspiration to technical perfection [Gul'ko, 2012, s. 140].

Researchers C. Axell, J. Hallström, J.-E. Hagberg [Axell et al., 2014] studied images of technology and how technology is linked to sustainable development in Swedish children's literature as the technology 
plays a decisive role in reducing the conflict between growing economic activities and reductions in the use of natural resources. The scientists summarized traditional values in Sweden which are considered to be "a part of everyday life for many generations" [Axell et al., 2014]: a Swede should be industrious and thrifty, support his family, manage the resources he has got and turn means and responsibilities over to the next generation when that time comes.

C. Axell, J. Hallström, J.-E. Hagberg [Axell et al., 2014] identified four main ways in which technology is portrayed in some Swedish children's books:

1. Servant mode: technology is a powerful assistant to man and a tool to fulfill needs, wishes and dreams;

2. Deterministic mode: technology is something that has escaped from man's control;

3. Benevolent mode: technology is a loyal and 'equal' companion to man;

4. Nostalgic mode: 'older technologies' are better or more natural than modern (or the latest) technologies and old technology is attributed a higher value.

Books about Pettson propagate the nostalgic mode: "Technology is a natural tool in a rural world. The contact with nature retains morality and balance. Society rests on an eco-centric vision, which means that the ecosystems, other species and the landscapes have intrinsic values, regardless of their importance to man. There is a connection to virtues that, in a country like Sweden, have been a part of everyday life for many generations in many rural and agrarian communities" [Axell et al., 2014].

It's hardly possible for Pettson to live without creating and constructing things which he finds useful in everyday life. When a good idea comes to his mind he can spend hours in his tool shed thinking, making calculations and doing arts and crafts. Without a doubt the most impressive invention is his mechanical Santa for Findus [Nordqvist, The Mechanical Santa, 2015]. Pettson wants to make a surprise for his cat and tells him that he is busy with inventing a machine that can feed the stove with wood sticks, which in reality is going to be a Santa Claus kind of robot.

All his inventions are ecologically friendly and cause no harm to the nature and living beings. An example of such inventions is an alarm sys- 
tem which he constructs in order to protect his hens from a hen-hunting fox [Nordqvist, Findus and the Fox, 2014]. Pettson's neighbour Gustavsson tells him that a fox has taken his chicken, that's why he offers Pettson to take his gun and shoot it next time when it comes to his hen house. But Findus feels pity for the fox and offers Pettson to outwit it. Pettson and Findus create a plan how to outwit the fox: Pettson makes a toy chicken and stuffs it with pepper in order to scare away the fox as soon as it catches the chicken and starts sneezing. Findus offers to make the effect even greater by adding fireworks to make loud noises and fire scare the fox even greater. And to completely horrify the fox Findus proposes to use a ghost which will be played by Findus himself. To do this he will have to wear a bed sheet and swing down from the attic onto a tree using a rope. Therefore, the characters manage to scare not only the fox but their neighbour as well using the materials at hand. So, readers can see that the main character is really keen on inventions and tries to create something new in any situation.

\section{COMMUNICATION AND NATIONAL CHARACTER}

Speaking about culture and cross-cultural communication it is important to pay attention to the manner of communication characteristic for the representatives of a particular culture and the way they interact with others. Researchers point out the following specific features of the Swedish character [Pishhik et al., 2017]: persistence, punctuality, precision, responsibility and reliability in relations, standoffishness, striving for solitude, deliberate conflict avoidance, tendency to keep their aggression at bay, etc. While reading books by S. Nordqvist we notice some of those features with Pettson. His striving for solitude becomes evident, he does not look for his neighbours' company, he feels quite comfortable with his cat. It's worth noting that all characters - major and minor ones - address each other in an informal way ('du' which is singular for 'you' in English). This reflects one of the Swedish habits to address people they know as well as those they don't by using the 'du' pronoun, which illustrates their friendly and informal attitude.

When analyzing Findus' manner to communicate we realize that he is always very emotional, most of his phrases are exclamatory. Verbs that S. Nordqvist uses when describing cat's speech ('exclaimed', 'shouted, 'yelled', 'screamed', 'cried', etc.) illustrate his emotional nature. Very 
often Findus behaves like a child (he 'wines', 'gets offended', 'sniffs', 'gets stubborn'). But Pettson's reaction to all his actions is calm, reserved and reasonable ('assured', 'proposed', 'explained', 'calmed him down', etc.). At the same time Pettson doesn't use imperatives, but offers and suggestions ('I think we should', 'maybe', 'it seems that..., etc.). It is evident that irrespective of the circumstances Pettson remains cold-blooded. Findus' lively and capricious speech does not unbalance Pettson and does not provoke scandals and collisions.

Summing up, it's necessary to emphasize the importance of the socio-cultural competence for successful communication, since it contributes to the individual's awareness of the peculiarities of the own and other cultures. A respectful attitude, understanding and acceptance of a different culture are established in the process of socio-cultural competence formation, which favorably leads to positive development of economical, political, cultural, scientific and other contacts with representatives of a different cultural background. This competence might be formed in a number of ways, for instance, within the course of a foreign language, history, literature, both within the educational system and outside it. Reading books, even translated ones, allows to acquire a fairly wide range of knowledge about different spheres of foreign society.

The analysis of S. Nordqvist's Pettson and Findus book series made it possible to highlight some key aspects, giving the reader a general idea about Sweden, its objective/real geographic, historical, economic, cultural and other characteristics, reflected in the imaginary world of an old man and a cat.

\section{REFERENCES}

Andreyeva O. A., Tuleubaeva Sh. K., Ganyukova A. A., Tentekbaeva Zh. M. Mezhkul'turnoe obshchenie kak sposob dostizheniia mezhkul'turnoi kommunikativnoi kompetentsii [Cross-cultural Communication as a Way of Achievement of Cross-cultural Communicative Competence]. European Researcher, 2015, vol. 92, iss. 3, pp. 208-213. (In Russian)

Arnö-Berg I. Folk Costumes of Sweden, a Living Tradition. ICA bokförlag, 1976. $236 \mathrm{~s}$.

Axell C., Hallström J., Hagberg J.-E. Images of Technology and Sustainable Development in Swedish Children's Literature. Australasian Journal of Technology Education. Published online October, 2014. Available at: www.researchgate. net/publication/266475436 
Bezuglova N.P. Mezhkul'turnaia kommunikatsiia v mezhdistsiplinarnom pole [Intercultural communication in the interdisciplinary field]. Vestnik Moskovskogo gosudarstvennogo universiteta kul'tury $i$ iskusstva, 2017, no. 6 (80), pp. 85-92. (In Russian)

Gul'ko N.N. Natsional'no-psikhologicheskie osobennosti naseleniia skandinavskikh stran [National psychological peculiarities of the inhabitants of the Scandinavian countries]. Evraziya: duhovnye tradicii narodov, 2012, no. 2 (2), pp. 139-151. (In Russian)

Hall Th., Dunér K. Svenska hus: landsbygdens arkitektur — från bondesamhälle till industrialismav. Carlsson bokförlag AB, 2005. $256 \mathrm{~s}$.

Kaplunova N.S. Sotsiokul'turnaia kompetentsiia kak osnova sotsiokul'turnogo obshcheniia [Sociocultural competence as the basis for sociocultural communication]. Kul'tura. Nauka. Integraciya, 2012, no. 2 (18), pp. 100-104. (In Russian)

Khavanskaya M. A. Rol' fonovykh znanii v inoiazychnom obshchenii [The role of background knowledge in foreign language communication]. Nauchnoe mnenie, 2015, no. 4-2, pp. 156-158. (In Russian)

Kryukova E.I. Literaturnye issledovaniia kak sredstva uproshcheniia protsessa mezhkul'turnoi kommunikatsii [Literary studies as the means of facilitating cross-cultural communication]. Mezhdunarodnyi nauchno-issledovatel'skii zhurnal, 2016, no. 11-2 (53), pp. 37-38. (In Russian)

Mandzhiev A. A., Chernova N.I. Inoiazychnyi khudozhestvennyi tekst kak instrument razvitiia sotsiokul'turnoi kompetentsii uchashchikhsia [Foreign language fiction text as an instrument for developing sociocultural competence of pupils]. Mir obrazovaniia - obrazovanie v mire, 2014, no. 1 (53), pp. 153156. (In Russian)

Nordqvist S. Imeninnyi pirog [Pancake Pie]. Belaia vorona, 2014. 24 s. (In Russian)

Nordqvist S. [When Findus was little and dissapeared]. Belaia vorona, 2014. 24 p. (In Russian)

Nordqvist S. Mekhanicheskii Ded Moroz [The Mechanical Santa]. Belaia vorona, 2015. 118 p. (In Russian)

Nordqvist S. Okhota na lis [Findus and the Fox]. Belaia vorona, 2014. 24 p. (In Russian)

Nordqvist S. Petson grustit [Findus goes fishing]. Belaia vorona, 2014. 24 p. (In Russian)

Nordqvist S. Rozhdestvo v domike Petsona [Findus at Christmas]. Belaia vorona, 2014. 24 s. (In Russian)

Plahtienko O. P. Sven Nurdkvist - avtor i illyustrator knizhek-kartinok o starichke Petsone i kotenke Finduse [Sven Nordqvist - author and illustrator of picture books about old man Pettson and Cat Findus]. Detskaia kniga: avtor-hudozhnik-chitatel'. Materialy mezhregional'noi nauchnoi konferentsii. Iaroslavl', Iaroslavskii gosudarstvennyi pedagogicheskii universitet im. K. D. Ushinskogo Publ., 2016, pp. 89-94. (In Russian) 
Ptichnikova G. A. Shvedskii «Neoehmpirizm»: k voprosu o poiskakh natsional'nogo svoeobraziia v evropeiskoi arkhitekture 1940-h gg. [Swedish 'New Empiricism': Towards Searching of National Originality in European Architecture of the 1940s]. Voprosy vseobshchei istorii arkhitektury, 2016, no. 2 (7), pp. 229-240. (In Russian)

Rzaeva G. N., Mustafaeva M.R., Mamedova D. F. Mezhkul'turnaya kommunikaciya $\mathrm{v}$ sovremennoj sisteme obrazovaniya [Cross-cultural communication in contemporary educational system]. Global'nyj nauchnyj potencial, 2017, no. 1 (70), pp. 32-34. (In Russian)

Shvedova K. E. Shvedskij narodnyj kostyum: tradicii i sovremennost' [Swedish folk costume: tradition and modernity]. Molodezhnyj vestnik Sankt-Peterburgskogo gosudarstvennogo instituta kul'tury, 2016, no.2 (6), pp. 175-179. (In Russian)

Surovneva A. A., Prohoda P. V. Mezhkul'turnaya kommunikaciya kak global'naya problema sovremennogo mira [Cross-cultural communication as a global problem of contemporary world]. Nauchnye trudy Kubanskogo gosudarstvennogo tekhnologicheskogo universiteta, 2017, no. 6, pp. 389-396. (In Russian)

Swahn J.-Ö. Swedish traditions. Ordalaget Bokförlag, 2012. 159 s.

Volkova E.V. Aktualizaciya fenomena sociokul'turnoj kompetencii v usloviyah globalizacii [Actualization of the sociocultural competence phenomenon in terms of globalization]. Teoriya i praktika obshchestvennogo razvitiya, 2014, no. 19, pp. 230-232. (In Russian)

Voluzheva T.V., Arhipov I. B. Formirovanie sociokul'turnoj kompetencii cherez prizmu original'nyh nemeckih skazok [The acquisition of the cultural awareness by means of the original german fairytales]. Innovacii v nauke, 2013, no. 19, pp. 62-66. (In Russian)

\section{Т. О. Коноплева, О. В. Печинкина}

Северный (Арктический) федеральный университет имени М. В. Ломоносова ОТРАЖЕНИЕ КУЛЬТУРЫ ШВЕЦИИ В КНИГАХ СВЕНА НУРДКВИСТА (НА ПРИМЕРЕ СЕРИИ КНИГ О ПЕТСОНЕ И ФИНДУСЕ)

Для цитирования: Konopleva T. O., Pechinkina O.V. Learning about Swedish culture from Sven Nordqvist's books (case-study: Pettson and Findus book series) // Скандинавская филология. 2018. Т. 16. Вып. 2. С. 340-355. https://doi.org/ $10.21638 / 11701 /$ spbu21.2018.210

В условиях мировой глобализации знание особенностей и ценностей иных культур становится необходимым условием эффективной коммуникации, способствует более глубокому осознанию родной культуры, формирует толерантность и содействует установлению и развитию политических, экономических, культурных и иных контактов между странами. Одним из источников приобретения необходимых знаний служат художественные тексты, в которых авторы воссоздают объективную реальность своей страны. Профессионально переве- 
денная и ярко иллюстрированная детская литература позволяет познакомиться с особенностями культуры другой страны в раннем возрасте. Анализируется отражение элементов культуры Швеции в книгах шведского писателя-иллюстратора Свена Нурдквиста. Книги этого современного автора, а именно серия книг про Петсона и Финдуса, пользуются большой популярностью во многих странах мира. Главный герой книги - Петсон, немолодой мужчина, живущий в одиночестве в традиционном сельском домике с садом на краю шведской деревушки. Однажды в его размеренной жизни появляется беспокойный и озорной котенок, которого Петсон без долгих раздумий называет Финдусом. С этого момента ему приходится постоянно искать выход из проблемных ситуаций, в которые попадает Финдус. Книги о Петсоне и Финдусе переведены на многие языки, по ним сняты мультфильмы и разработаны образовательные программы. Особенностью книг являются иллюстрации автора - профессионального художника, которые дополняют текстовую информацию о Швеции, ее географических особенностях, бытовом укладе сельских жителей, традициях, праздниках, национальной кухне, изобретениях и т.д. Свен Нурдквист талантливо изображает повседневный уклад жизни Швеции. Читатели получают возможность приобрести знания о культуре Швеции, необходимые для эффективного взаимодействия с представителями других культур.

Ключевые слова: Свен Нурдквист, шведская культура, межкультурная коммуникация, традиции.

\section{Tatiana Konopleva}

Senior Lecturer,

Northern (Arctic) Federal University named after M. V. Lomonosov,

17, nab. Severnoy Dviny, Arkhangelsk, Russia, 163002

E-mail: t.konopleva@narfu.ru

\section{Olga Pechinkina}

PhD (Education), Associate Professor,

Northern (Arctic) Federal University named after M. V. Lomonosov,

17, nab. Severnoy Dviny, Arkhangelsk, Russia, 163002

E-mail: o.pechinkina@narfu.ru

Received: August 9, 2018

Accepted: September 27, 2018 